\title{
Perubahan pengetahuan setelah edukasi foto ronsen di bidang kedokteran gigi pada siswa SMAN1 Cipatat menggunakan media animasi
}

\author{
Nur Alya Nazerin ${ }^{1 *}$, Lusi Epsilawati ${ }^{1}$, Anne Agustina Suwargiani ${ }^{2}$ \\ ${ }^{1}$ Departemen Radiologi Kedokteran Gigi Universitas Padjadjaran \\ ${ }^{2}$ Departemen Ilmu kesehatan Gigi Masyarakat Universitas Padjadjaran
}

*Korespondensi: alyanazerin@gmail.com

\begin{abstract}
ABSTRAK
Pendahuluan: Radiografi gigi merupakan salah satu pemeriksaan wajib yang digunakan di kalangan dokter gigi untuk membantu dalam menentukan diagnosis yang tepat dalam rongga mulut. Namun, radiografi gigi menghasilkan bahaya yang tidak terduga yaitu radiasi sinar-X yang memberi dampak buruk ke tubuh manusia. Tujuan dari penelitian ini adalah untuk mengetahui perubahan pengetahuan setelah edukasi radiografi gigi di kalangan siswa SMAN 1 Cipatat menggunakan media animasi. Metode: Penelitian ini dirancang dengan metode deskriptif. 32 siswa kelas VI MIPA 2 di SMAN 1 Cipatat dipilih menjadi responden berdasarkan teknik total sampling. Perubahan pengetahuan setelah edukasi menggunakan media animasi diukur dengan memberikan kuesioner sebelum dan sesudah edukasi. Hasil: Hasil penelitian ini menunjukkan perubahan pengetahuan setelah pendidikan radiografi gigi di SMAN 1 Cipatat menggunakan media animasi meningkat. Untuk survei pra-tes, tingkat pengetahuan radiografi gigi tingkat tinggi adalah 19 siswa $(59,375 \%)$. Sementara, untuk survei pasca-tes, tingkat radiografi gigi tingkat tinggi adalah 31 siswa (96,875\%). Kesmpulan: Kesimpulannya, penelitian ini menunjukkan adanya penambahan pengetahuan radiografi gigi yang signifikan setelah edukasi menggunakan media animasi.
\end{abstract}

Kata kunci: Restorasi komposit, free-hand layering technique

\section{Change of knowledge after dental radiography education among High School 1 Cipatat students using animation media}

\begin{abstract}
Introduction: Dental radiography is one of mandatory examination used among the dental operator which helps in determine the definitive diagnosis of disease occurred in the oral cavity. However, the dental radiography still can produce unexpected hazard which is the X-ray radiation that may affect the human body. The purpose of this research was to know the change of knowledge after dental radiography education among SMAN 1 Cipatat Students using Animation Media. Methods: This research was designed with descriptive method. Thirty-two students from Class VI MIPA 2 in SMAN 1 Cipatat were selected as the respondents based on total sampling technique. The change of knowledge after dental radiography education using animation media was measured by giving a questionnaire before and after the education. Results: The result of this research showed that the change of knowledge after dental radiography education among SMAN 1 Cipatat using animation media was increasing. For the pre-test survey, the amount of respondents with high level of dental radiography knowledge was 19 students (59.375\%). While, for post-test survey, the amount of respondents with high level of dental radiography was 31 students (96.875\%). Conclusion: As conclusion, it showed that the dental radiography knowledge has significance different after education using animation media.
\end{abstract}

Keywords: Knowledge, Dental Radiography, Education, Animation media 


\section{PENDAHULUAN}

Radiografi gigi merupakan salah satu pemeriksaan wajib yang digunakan dalam praktek dokter gigi untuk membantu dokter gigi mengamati kondisi rongga mulut yang tidak dapat dilihat dengan mata telanjang dan menentukan diagnosis yang akurat. Namun, radiografi dapat menghasilkan potensi bahaya yang dapat mempengaruhi tubuh manusia hingga merusakkan jaringan dan dapat menyebabkan kematian. ${ }^{1}$ Dengan alasan tersebut, masyarakat perlu dididik tentang pengetahuan penggunaan radiografi gigi dan bahaya radiasi termasuk perlindungan agar sadar tentang hal ini. Pasien perlu tercerahkan sehingga pengambilan radiografi berjalan dengan baiki. ${ }^{2}$ Kesehatan adalah masalah kompleks terutama apabila melibatkan strategi pencegahan penyakit dan promosi kesehatan. ${ }^{3}$

Metode pendidikan dengan bantuan alat bantu melibatkan lebih banyak rasa tubuh dapat memberikan dampak terhadap pemahaman target. ${ }^{4}$ Oleh karena itu, untuk penelitian ini metode pendidikan yang telah dipilih adalah media animasi. Dengan menggunakan metode ini, metode ini bisa lebih efektif dan menarik karena menggabungkan suara dan gambar yang bergerak dalam penyampaian informasi ke audisi. ${ }^{4}$ Penelitian ini dilaksanakan di SMAN 1 Cipatat yang berlokasi di Cipatat, Kabupaten Bandung Barat di Jawa Barat. Berdasarkan data profil dari Cipatat, ada banyak fasilitas kesehatan yang tersedia iaitu tiga Pusat Kesehatan Masyarakat / Pusat Kesehatan Masyarakat (Puskesmas) tetapi hanya tujuh dokter yang tersedia di tahun $2016 .{ }^{5}$ Data tersebut dapat menunjukkan, masyarakat Cipatat masih kekurangan dalam pelayanan kesehatan dan pendidikan kesehatan terutama tentang radiografi gigi. Selain itu, pendidikan kesehatan diberikan di kalangan anak-anak karena kelompok ini masih dalam tahap belajar dan dapat memahami informasi yang diberikan dengan mudah. ${ }^{3}$ Tujuan penelitian ini adalah untuk mengetahui perubahan pengetahuan setelah pendidikan radiografi gigi pada siswa SMAN 1 Cipatat menggunakan media animasi.

\section{METODE}

Data untuk penelitian ini akan diperoleh dengan menggunakan metode deskriptif dengan melakukan survei pada siswa di SMAN 1 Cipatat tentang perubahan pengetahuan pada radiografi gigi setelah memberi pendidikan menggunakan media animasi menggunakan kuesioner untuk pre-test dan posttest. (Tabel 1 dan 2) Penelitian dilakukan di SMAN 1 Cipatat, Jl. Desa Ciptaharja, No. 35, Ciptaharja, Cipatat, Bandung Barat pada Februari 2018.

Penelitian ini menggunakan beberapa instrumen dan alat termasuk kuesioner untuk pre-test dan post-test, alat tulis, informed consent dari untuk responden, tabel pengumpulan data untuk evaluasi pengetahuan sebelum dan sesudah pendidikan termasuk evaluasi untuk perubahan pengetahuan. Selain itu, kamera, laptop, video animasi yang dipersiapkan, proyektor, barang untuk siswa dan suvenir untuk guru digunakan selama acara penelitian. Populasi yang akan terlibat adalah semua siswa SMAN 1 Cipatat yang bersedia memberikan kontribusi dalam pendidikan ini. Teknik yang digunakan adalah total sampling dimana peneliti akan melakukan penelitian kepada seluruh siswa SMAN 1 Cipatat dari Kelas XI MIPA 2.

\section{HASIL}

Tabel 1. Statistik deskriptif pengetahuan sebelum dan sesudah Pendidikan radiografi gigi Variabel / KategoriPengetahuan Radiografi Gigi

\begin{tabular}{ccccc}
\hline Variabel / Kategori & \multicolumn{2}{c}{ Pengetahuan Radiografi Gigi } & Selepas Edukasi \\
\hline & Sebelum Edukasi & Frekuansi & 0 \\
\hline Rendah & Frekuansi & Persentase & 0 & 1 \\
Sedang & 0 & 40.625 & 3.125 \\
Tinggi & 13 & 59.375 & 31 & 96.875 \\
Jumlah & 19 & $\mathbf{1 0 0}$ & $\mathbf{3 2}$ \\
\hline
\end{tabular}


Tabel 4 menunjukkan deksripsi pengetahuan responden tentang radiografi gigi sebelum dan sesudah Pendidikan. 13 siswa (40.625\%) termasuk dalam kategori sedang terhadap pengetahuan radiografigigi sedangkan 19 siswa lainnya (59.375\%). termasuk dalam kategori

Diagram 1. Grafik pengetahuan radiografi gigi sebelum dan sesudah pendidikan

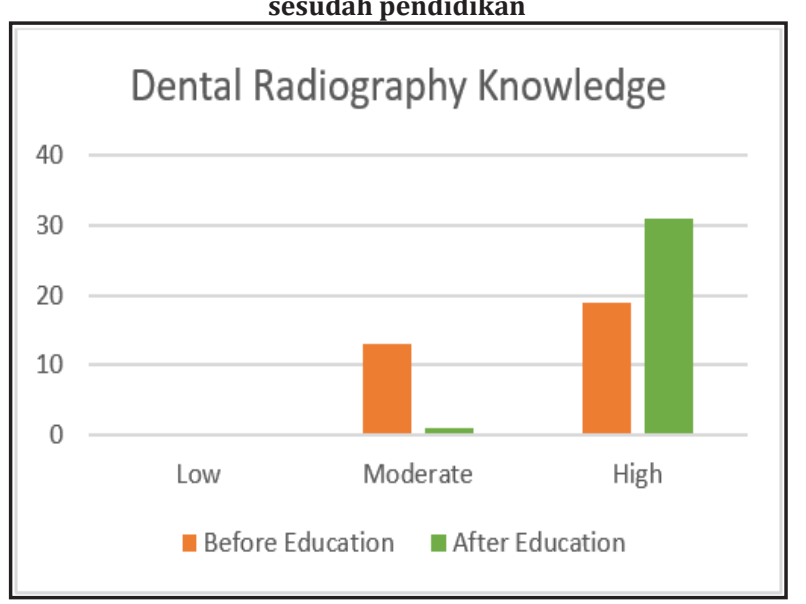

tinggi terhadap pengetahuan radiografi gigi sebelum edukasi. Setelah edukasi radiografi gigi,hanya 1 siswa (3.125\%) memiliki tingkat pengetahuan radiografi gigi sedang sedangkan 31 siswa yang lain (96.875\%) memiliki tingkat pengetahuan radiografi gigi yang tinggi.

Diagram 2. Pie-chart perubahan pengetahuan radiografi gigi

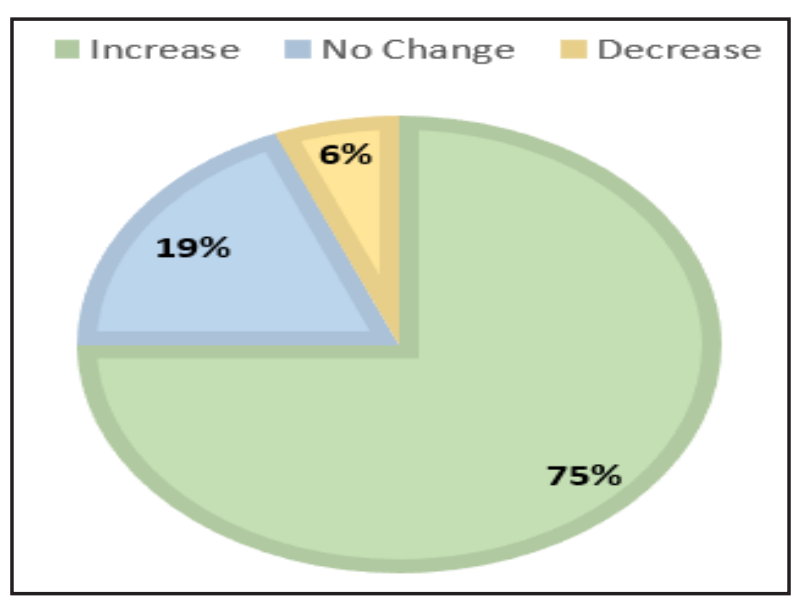

Tabel 2. Statistik deskriptif perubahan pengetahuan radiografi gigi

\begin{tabular}{cccc}
\hline Variabel & Kategori & Frekuensi & Persentase (\%) \\
\hline Perubahan Pengetahuan & Meningkat & 24 & 75.00 \\
Radiografi Gigi & Tiada Perubahan & 6 & 18.75 \\
& Menurun & 2 & 6.25 \\
\hline Jumlah & & $\mathbf{3 2}$ & $\mathbf{1 0 0}$ \\
\hline
\end{tabular}

Tabel 5 menunjukkan perubahan pengetahuan radiografi gigi setelah menerima pendidikan dengan menggunakan media animasi. Pengetahuan 24 siswa meningkat (75\%), pengetahuan 6 siswa tidak berubah (18.75\%) dan 2 siswa mengalami penurunan $(6.25 \%)$.

\section{PEMBAHASAN}

Tabel 4 menunjukkan pengetahuan responden sebelum dan sesudah pendidikan radiografi gigi. Sebelum pendidikan radiografi gigi, terlihat bahwa 19 responden $(59,375 \%)$ pada tingkat tinggi dan 13 responden $(40,625 \%)$ pada tingkat sedang. Dari data yang diperoleh dari survei pre-tes, dapat diketahui bahwa siswa memiliki pengetahuan yang cukup tentang dasar radiografi gigi karena jumlah responden dengan tingkat pengetahuan yang tinggi lebih dari tingkat sedang dan tiada responden pada tingkat rendah pengetahuan. Selama penelitian dilakukan, siswa dapat mengisi kuesioner dengan mudah dan mendapatkan nilai tinggi. Selain itu, terbukti bahwa sekolah memberikan sistem pembelajaran dan mata pelajaran yang baik kepada siswa. Pembelajaran yang digunakan adalah Kurikulum 2013 di mana telah termasuk pengetahuan tentang kesehatan. ${ }^{6}$ Di samping itu, sekolah menyediakan lab komputer dengan akses internet yang baik dan cepat. Dengan demikian, para siswa dapat menggunakan manfaat fasilitas tersebut untuk mencari semua informasi untuk belajar.

Selain itu, kesadaran orang tua di Desa Cipatat tentang pentingnya belajar untuk anak tinggi. Dari hasil yang dilakukan, terlihat bahwa sekitar tiga perempat orang tua hanya seorang karyawan dengan gaji sedang dan sekitar 20 orang tua hanya belajar sampai sekolah menengah. Hanya sejumlah kecil orang tua yang memiliki pekerjaan yang lebih baik dengan gaji yang lebih baik. Namun, orang tua tetap mengirim anak-anak ke sekolah bahkan orang tua tidak memiliki tingkat pendidikan yang tinggi karena mereka percaya bahwa dengan pengetahuan yang 
diberikan dari sekolah dapat membuat anak-anak menjadi manusia yang lebih baik di masa depan.

Tabel 4 juga menunjukkan pengetahuan responden setelah pendidikan radiografi gigi di mana 31 siswa (96,875\%) pada tingkat tinggi dan hanya satu responden $(3,125 \%)$ pada tingkat sedang. Hasil ini menunjukkan bahwa jumlah responden dengan tingkat tinggi terhadap pengetahuan radiografi gigi meningkat setelah pendidikan radiografi gigi menggunakan media animasi.

Dari survei pre-test, hanya 19 responden yang memiliki tingkat pengetahuan tinggi dan meningkat menjadi 31 siswa dengan tingkat pengetahuan tinggi. Pendidikan radiografi gigi penting di kalangan masyarakat tetapi sulit untuk menyampaikan secara verbal dan membuat seseorang mengerti dengan sepenuhnya. Oleh karena itu, program pendidikan kesehatan harus semenarik mungkin tanpa mengurangi isi yang penting. ${ }^{7}$ Kebutuhan media sebagai alat bantu dalam menyampaikan informasi kesehatan gigi memegang peranan penting untuk meningkatkan kemampuan siswa mengingat. Dengan menggunakan media animasi dalam pendidikan radiografi gigi ini, informasi penting tentang radiografi gigi dapat diberikan dengan mudah kepada siswa. Hal ini dibuktikan oleh perbedaan yang signifikan antara pengetahuan sebelum dan sesudah pendidikan karena informasi disediakan dalam video animasi dengan kata-kata yang menarik, audio dan gambar. Hasil ini memiliki hasil yang sama dalam penelitian yang dilakukan oleh Yanti dan teman-teman (2017) yang menunjukkan perbedaan yang signifikan pada pengetahuan dan skor OHI-S sebelum, setelah dan seminggu setelah pendidikan kesehatan gigi menggunakan pemutaran video kartun. Tabel 5 menunjukkan bahwa ada perubahan pengetahuan setelah menerima pendidikan radiografi gigi yang 24 responden (75\%) meningkat karena mereka memperhatikan selama pendidikan dan memiliki perilaku yang menentukan untuk belajar. Selain itu, 6 responden $(18.75 \%)$ tidak mengalami perubahan pengetahuan radiografi gigi. Ini mungkin terjadi karena siswa ini tidak peserta dan sepenuhnya memahami selama teori proses pembelajaran.

Pendidikan yang diberikan menggunakan media animasi. Pada akhir pendidikan, ada bagian pertanyaan terbuka yang telah dibuat selama 30 menit untuk memberikan kesempatan bagi para siswa bertanya apa pun mengenai pendidikan. Sayangnya, hanya 2-3 siswa yang mengajukan pertanyaan dan siswa lainnya hanya diam dan memutuskan untuk tidak bertanya. Terakhir, perubahan pengetahuan dari dua responden $(6.25 \%)$ menurun. Ini terjadi karena ada beberapa siswa yang tidak sepenuhnya berpartisipasi selama pendidikan dan berbicara satu sama lain di belakang kelas. ${ }^{8}$

\section{KESIMPULAN}

Berdasarkan hasil penelitian ini, perubahan pengetahuan setelah radiografi gigi pada siswa SMAN 1 Cipatat menggunakan media animasi semakin meningkat.

\section{DAFTAR PUSTAKA}

1. Issrani R. Intraoral C-Ray Films- A Walk through History : Research \& Reviews. J Dent Sci. 2017;5(1):8-10

2. Ashok NG, Kumar VJ. Patients Perception on Dental Radiographs: A Questionnaire-based Study. Int J Orofacial Biology. 2017;1(1):28-30. Available from: http://www.ijofb.org.

3. Ramesh Kumar SG, Aswath Narayanan M B, Jayanthi D. Comparison of oral hygiene status before and after health education among 12-18-year-old patients. J Indian Assoc Public Health Dent 2016;14:121-5

4. Tandilangi M, Mintjelungan C, Wowor VNS Efektivitas dental health education dengan media animasi kartun terhadap perubahan perilaku kesehatan gigi dan mulut Siswa SD Advent 02 Sario Manado. J e - Gigi. 2016;4(2):106-108

5. BAPPEDA (Badan Perencanaan Pembangunan Daerah Kabupaten Bandung Barat). Basis Data Pembangunan Kabupaten Bandung Barat 2016. [Internet] [3 january 2018] 2016. Available from: http://bandungbaratkab.go.id/ media/artikel//18/c3fdf125f4-basis-datapembangunan-tahun-2016.pdf.

6. Kementerian Pendidikan dan Kebudayaan. SMAN 1 Cipatat: Data Pokok Pendidikan Dasar dan Menengah.cited:[8february2018]2016.Available from: http://dapo.dikdasmen.kemdikbud. go.id/sekolah/0B1482BB38506E9DEB5F\#. [8 February 2018]

7. Notoatmodjo S. Promosi Kesehatan dan Perilaku Kesehatan. Ed.2 . Jakarta: Rineka. 2012.

8. CiptaYanti GM, Alamsyah RM, Natassa SE. Effectiveness of dental health education using cartoons video showing method on knowledge and oral hygiene of deaf children in Yayasan Murni Medan. Int J Applied Dent Sci. 2016;3(2):87-89 